MATEC Web of Conferences 53, 01045 (2016)

DOI: $10.1051 /$ matecconf/20165301045

(C) Owned by the authors, published by EDP Sciences, 2016

\title{
Forecasted Payback Period in the Case of Energy-Efficient Activities
}

\author{
Alexander Gorshkov ${ }^{1}$, Vera Murgul ${ }^{1, a}$ and Olena Oliynyk ${ }^{2}$ \\ ${ }^{1}$ St. Petersburg State Polytechnical University, Polytechnicheskaya st. 29, St. Petersburg, 195251, Russia \\ ${ }^{2}$ National Aviation University, Kosmonavta Komarova, 1, Kiev, 03680, Ukraine
}

\begin{abstract}
There is a very important governmental issue, which is to secure energy efficiency of buildings under design. This issue is stated in the federal law, governmental regulations and orders of the subject Ministries. However, issues related to energy-efficiency are appropriate for both existing buildings and the ones under design. Total volume of buildings constructed according to new heat protection rules and regulations valid since 2000 , accounts for $5 \%$ of the total volume of all the housing stock in the Russian Federation. Consequently, reduction of heat energy consumption in houses built before 2000 is getting more crucial in the nearest future. Nowadays there is a national programme to execute major repair works in the existing buildings. It is important to have this programme correlated with the energy-saving program. However, the economy of investment projects shouldn't be disregarded when running this programme. Energy-efficient activities should contribute to a better return on investment, and reduction of the energy consumed.
\end{abstract}

\section{Introduction}

One of the ways to reduce heat losses for heating can be additional insulation of exterior building envelopes (walls, slabs, attic slabs, exterior doors, etc.). Increase in insulation in building envelopes leads to reduction of heat losses due to transmission. The less there are heat losses in a building the less amount of heat energy is required to supply to the building from a heat supply source in order to recover heat losses due to transmission (provided the requirements for microclimate are met) [1-8]. Thus, insulation leads to reduction of the energy consumed in the building, and, consequently, to cutdown of heating costs [8]. The economic effect due to this energy-saving activity is based on this principle. However, it will require additional capital investments. Economic efficiency of the energysaving activity to be introduced can be featured by its payback period. In the case of the payback period less than estimated service life and maintenance duration of the technological solution to be applied [9-12], it should be stated as economically viable, i.e. energy-efficient.

As to insulation in existing buildings it should be noted that buildings constructed according to regulations valid before the introduction of the Federal Law of the Russian Federation "On energyefficiency ...” (FL № 261 dated 23 November 2009) are outdated (but not from physical standpoint). They became outdated due to insufficient level of heat protection of exterior envelopes. With the energy-saving programme coming into existence, standard requirements for heating protection in

\footnotetext{
${ }^{\mathrm{a}}$ Corresponding author: october6@list.ru
} 
buildings were strengthened. For this reason existing buildings do not comply with the new standards. And there is only one opportunity to make them conform to new rules and regulations, which is insulation of existing buildings at up-to-date or even higher level.

The method to calculate the payback period of energy-efficiency investments is proposed in the works $[13,14]$. The method to estimate the level of heat protection efficiency in the case of exterior envelopes using net present value (NPV), obtained as a result of the energy-saving activity given, is demonstrated in the work [15]. The calculation method to estimate economic efficiency of energysaving translucent structures is stated in the industry standard IS UMPP (Union of Manufacturers of Polymer Profiles) 4.5-2012 [16].

This survey deals with the calculation method of the payback period in the case of investments meant for façade insulation in the existing building.

\section{Calculation model}

A calculation method of specific costs has been used herein to calculate the payback period of investments meant for façade insulation in the existing block of flats. The following basic equation is given to calculate a simple payback period $[17,18]$.

$$
T=\frac{K_{2}}{Э_{1}-Э_{2}}=\frac{\Delta K}{\Delta \ni} .
$$

where

$\Delta \mathrm{K}$ - difference of capital costs meant for renovation per $1 \mathrm{~m} 2$ of exterior walls, $\mathrm{Rub} / \mathrm{m} 2(\Delta \mathrm{K}=$ $\mathrm{K} 2$, as $\mathrm{K} 1=0$ );

Э1 - operation and maintenance costs allowing for heat losses through $1 \mathrm{~m} 2$ of an exterior wall during one heating season before insulation works of exterior walls are executed, Rub/ $\mathrm{m} 2$. per year;

Э2 - operation and maintenance costs allowing for heat losses through $1 \mathrm{~m} 2$ of an exterior wall during one heating season after insulation works of exterior walls, Rub/ $\mathrm{m} 2$ - per year;

$\Delta \ni$ - the difference between heat losses through $1 \mathrm{~m} 2$ of an exterior wall before and after insulation works of facades in the existing building $Э_{1}-Э_{2}$ are executed.

In the formula (1) annual savings per year $\Delta \ni, \mathrm{Rub} / \mathrm{m} 2$ to be achieved due to renovation of façades in the existing building and reducing transmission heat losses in the building can be determined as follows [14]:

$$
\Delta \ni=\left(U_{1}-U_{2}\right) \cdot \frac{0,024 \cdot H S D D}{1163} \cdot c_{h}
$$

where

$\mathrm{U} 1$ - heat transfer coefficient (U-value) of exterior walls in the existing building before renovation (insulation) works of the facades, $\mathrm{W} /(\mathrm{m} 2 \cdot \mathrm{K})$;

$\mathrm{U} 2$ - heat transfer coefficient (U-value) of exterior walls in the existing building after renovation (insulation) works of the facades, $\mathrm{W} /(\mathrm{m} 2 \cdot \mathrm{K})$;

HSDD - heating season degree-day, $\mathrm{K} \cdot$ day;

$0.024,1163$ - conversion factors;

$\mathrm{Ch}$ - cost of heat energy for heating in the dwelling area given, Rub/Gcal.

Let us remark here that the payback period calculated under the formula (1) does not allow for:

- the growth of rates for heating energy;

- loan interest (provided a loan for exterior walls insulation is taken);

- future discounted cash flows obtained as a result of the energy saving activity considered herein such as reducing of heat losses for heating..

Due to this reason the value of a non-discounted payback period, calculated under the formula (1), can be considered as an estimated one.

Provided a construction company or private individual implements insulation works using own 
(non-borrowed) resources then capital costs $\Delta \mathrm{K}$ will be equal to cost estimates. If an executive company uses a loan (a bank credit) to perform works on the basis of equal monthly installments (annuities) total investments into energy efficiency $\Delta \widetilde{K}$ should be determined under the formula:

$$
\Delta \widetilde{K}=m \cdot A \cdot \Delta K,
$$

where

$\mathrm{m}$ - a number of redemption periods (e.g., if there is a 1-year loan: $\mathrm{m}=12$, if there is a 2 -years loan: $\mathrm{m}=24$ and etc.);

A - annuity factor;

$\Delta \mathrm{K}$ - own resources of a performing company (investments without regard to loan payments).

Annuity factor A can be determined according to the formula:

$$
A=\frac{p_{l} \cdot\left(1+p_{l}\right)^{m}}{\left(1+p_{l}\right)^{m}-1},
$$

where

$\mathrm{p}_{1}$ - monthly interest of a bank loan rounded to two decimal places per payment frequency (e.g., in the case of $12 \%$ per annum and monthly payments ( 12 times per year): $\left.p_{1}=0.12 / 12=0.01\right)$;

$\mathrm{m}$ - the same as in the formula (3).

Coming from the analysis of the formulas (1) and (2), in particular, it follows that with the facades insulation project given herein $(\Delta \mathrm{U}=\mathrm{U} 1-\mathrm{U} 2)$ under climatic conditions of the area given $H S D D$, rate of return on investment depends just on the value of heat energy $C_{h}$ and its dynamics of change through time (rate growth for heat energy).

Rates for heating energy rise annually. It means that with every year (heating season) annual savings of monetary funds $\Delta \ni_{\mathrm{i}}$ will increase.

When considering the model it should be taken into account that money funds saved in subsequent years must be calculated on the basis of actual value of money in n years, i.e. future cash flows must be discounted.

Allowing for all the factors mentioned above, the forecasted payback period of investments meant for additional facades insulation should be determined using the following equation $[17,20]$ :

$$
T=\frac{\ln \left[1+\frac{\Delta \widetilde{K}}{\Delta \ni} \cdot \frac{(r-i)}{(1+i)}\right]}{\ln \left[\frac{1+r}{1+i}\right]}
$$

where

$$
\begin{aligned}
& \Delta \widetilde{K}-\text { the same as in the formula (3), Rub/m2; } \\
& \Delta \ni \text { - the same as in the formula (2), Rub/m2; } \\
& \mathrm{r} \text { - average annual growth of rates for heating energy; } \\
& \mathrm{i} \text { - discount rate. }
\end{aligned}
$$

The equation (5) makes it possible to calculate the payback period $\mathrm{T}$ of the energy-saving activity under consideration with due account for total capital costs to have it performed $\Delta \widetilde{K}$, loan payments $\left(\mathrm{P}_{1}\right)$, growth of the rate for heat energy ( $\mathrm{r}$ ), discounting of future cash flows (i), which can be achieved using fund savings due to implementation of such an energy-saving activity.

Let us remark that the equation (5) makes it possible to estimate the payback period of any energysaving activity or technical solution, including engineering one. It is highly important to evaluate its energy-saving potential capacity $\Delta \ni$ and capital costs $\Delta \widetilde{K}$ for its implementation.

As to the measure for future cash flows to be discounted, the following factors, which can make an impact on the value of future cash flows, can be considered: average inflation rate taken for a certain 
period (for instance, for 5 or 10 previous years), interest rate of the Russian Central Bank, return on investments (such alternative investments as a deposit) and others.

It should be pointed out that the equation (5) considers a number of time that denote time, in particular dynamics of rate growth for heat energy (expressed as $r$ ) and the rate (i), according to which discounting of future cash flows accumulated due to the energy-saving activity is estimated. Nowadays it's impossible to determine for sure how the variables may vary through time. Consequently, with the aim to estimate the forecasted payback period of energy-efficient investments, there are some probable scenarios how the variables in the equation (5) may change, and then choose the most probable one from the list of the data obtained.

\section{Calculation example}

Let's take the case of exterior walls insulation in the house built in Saint-Petersburg before 2000. Let's assume that a resistance to heat transfer of exterior walls complies with the requirements assigned for the envelopes before 2000 , and is equal to $\mathrm{R}_{0}{ }^{\text {bas }}=1.0 \mathrm{M} 2 \cdot \mathrm{K} / \mathrm{W}$.

Notes: an actual resistance to heat transfer of exterior walls in the building can be determined as the result of field measurements.

Having $\mathrm{R}_{0}{ }^{\text {bas }}=1.0 \mathrm{~m} 2 \cdot \mathrm{K} / \mathrm{W}$, we will find that $\mathrm{U} 1$ (see the formula (2)) is equal to $1.0 \mathrm{~W} /(\mathrm{m} 2 \cdot \mathrm{K})$. The amount of heat season grades in Saint-Petersburg is shown in the Table 1 and accounts for 4796 ${ }^{\circ} \mathrm{C}$. Heating in the building is a centralized (supply from a city HPP). The cost of heat energy $\mathrm{C}_{\mathrm{t}}=$ 1408.01 Rub/Gcal including VAT (see Order of the Committee on Tariffs of Saint-Petersburg dated 18.12.2013 state. № 527-p).

It is required to insulate exterior walls of the existing building to comply with the up-to-date specifications for the level of thermal protection (according to CR R23-02-2003 (Construction Rules and Regulations) «Thermal protection of buildings») and calculate the payback period of additional insulation activities. As an insulator let's take mineral wool products with a thin plaster layer as an insulator, which are assigned for facade works.

Table 1. Estimated climatic conditions for dwelling houses located in Saint-Petersburg.

\begin{tabular}{|c|c|c|c|}
\hline Indicator & Parameter & Units of measure & Calculated value \\
\hline Estimated outside air temperature & $\mathrm{t}_{\mathrm{out}}$ & ${ }^{\circ} \mathrm{C}$ & -26 \\
\hline $\begin{array}{c}\text { Average outside air temperature during the } \\
\text { heating period }\end{array}$ & $\mathrm{t}_{\mathrm{hp}}$ & ${ }^{\circ} \mathrm{C}$ & -1.8 \\
\hline Heating season duration & $\mathrm{z}_{\mathrm{hp}}$ & days/year & 220 \\
\hline Heating season degree day & $\mathrm{HSDD}$ & ${ }^{\circ} \mathrm{C} \cdot$ days/year & 4796 \\
\hline Estimated inside air temperature & $\mathrm{tB}$ & ${ }^{\circ} \mathrm{C}$ & 20 \\
\hline
\end{tabular}

Let us calculate the necessary thickness of the insulator, m. Let's use the following formula [9]:

$$
\delta_{r e q}=\left(R_{0}^{n e w}-R_{0}^{b a s}\right) \cdot \frac{\lambda_{i n s}}{r_{w b}},
$$

where

$R_{0}{ }^{\text {new }}$ - required (rated) value of the heat transfer resistance of exterior walls in the building, $\mathrm{m} 2 \cdot \mathrm{K} / \mathrm{W}$;

$R_{0}^{\text {bas }}$ - original (actual) value of the heat transfer resistance of exterior walls in the building before additional insulation works are made, $\mathrm{m} 2 \cdot \mathrm{K} / \mathrm{W}$;

$\lambda_{\text {ins }}$ - thermal conductivity of the insulator, $\mathrm{W} /(\mathrm{m} \cdot \mathrm{K})$;

$r_{w b}$ - heat transfer performance uniformity factor for additional insulation of the additional insulation layer.

Let's assume the coefficient of thermal conductivity for the mineral wool insulator under operation conditions (equal to $0.045 \mathrm{~W} /(\mathrm{m} \cdot \mathrm{K})$ ), and the heat transfer performance uniformity factor $r_{w b}$ equal to 
0.8 .

The required (rated) resistance to heat transfer for exterior walls in dwelling buildings under climatic conditions of Saint-Petersburg ( $\mathrm{HSDD}=4796{ }^{\circ} \mathrm{C} \cdot$ days $) 3.08 \mathrm{~m} 2 \cdot \mathrm{K} / \mathrm{W}$. The value of the resistance to heat transfer $3.08 \mathrm{~m} 2 \cdot \mathrm{K} / \mathrm{W}$ corresponds to the coefficient of thermal conductivity $\mathrm{U} 2=0.325 \mathrm{~W} /(\mathrm{m} 2 \cdot \mathrm{K})$. Taking into account the actual resistance to heat transfer in the building, which is not insulated, assumed as $1.0 \mathrm{~m} 2 \cdot \mathrm{K} / \mathrm{W}$, the required value of the thickness of the insulation layer, will be:

$$
\delta_{\text {req }}=\left(R_{0}^{\text {new }}-R_{0}^{\text {bas }}\right) \cdot \frac{\lambda_{\text {ins }}}{r_{w b}}=(3.08-1.0) \cdot \frac{0.045}{0.8}=0.117(\mathrm{~m}) .
$$

Consequently, to implement further calculations, let us assume that the required thickness value of the insulator made of mineral wool is equal to $120 \mathrm{~mm}$.

Capital costs for additional insulation of the exterior wall in the existing building with the thickness of the insulator equal to $120 \mathrm{~mm}$, which is subject to be covered with the thin plaster layer, $\Delta \mathrm{K}$ are assumed equal to $1950 \mathrm{Rub} / \mathrm{m} 2$, and they are as follows:

- $300 \mathrm{Rub} / \mathrm{m} 2$ is the cost of dry mixtures;

- $550 \mathrm{Rub} / \mathrm{m} 2$ is the cost of heat insulation (with an estimated price of the mineral wool insulator $4560 \mathrm{Rub} / \mathrm{m} 3)$;

- $60 \mathrm{Rub} / \mathrm{m} 2$ - the cost dish-shaped studs;

- $40 \mathrm{Rub} / \mathrm{m} 2$ - the cost of profiles;

- $1000 \mathrm{Rub} / \mathrm{m} 2$ - the cost of total construction and assembly works (service preparation, insulator installation, fixing to a lower layer, plasterwork).

As it is shown in the structure given herein the capital costs for additional insulation of the exterior walls in the existing building, insulation costs $(550 \mathrm{Rub} / \mathrm{m} 2)$ amount to less than $30 \%$ taken from the total costs (1950 Rub/m2).

Let us assume that a company has taken a loan at $12 \%$ annual interest rate for 3 years $(\mathrm{m}=36)$ to finance insulation works for the existing building.

In this case the annuity factor will be:

$$
A=\frac{p_{l} \cdot\left(1+p_{l}\right)^{m}}{\left(1+p_{l}\right)^{m}-1}=\frac{0,012 \cdot(1+0.012)^{36}}{(1+0.012)^{36}-1}=0.034 \text {. }
$$

Then total investments $\Delta \widetilde{K}$ to implement energy-saving project taking into account interest loan payments will account for (with annuity monthly payments):

$$
\Delta \widetilde{K}=m \cdot A \cdot \Delta K=36 \cdot 0.034 \cdot 1950=2386.8\left(R u b / m^{2}\right) .
$$

Let us calculate reduction value of the maintenance and operation costs during the first heating season due to energy saving activity introduction according to the formula (2):

$$
\Delta \ni=\left(U_{1}-U_{2}\right) \cdot \frac{0.024 \cdot H S D D}{1163} \cdot c_{h}=(1-0.325) \cdot \frac{0.024 \cdot 4796}{1163} \cdot 1408.01=94.1\left(R u b / m^{2}\right)
$$

Rate-growth dynamics for heat energy in Saint-Petersburg is shown in the Table 2.

Table 2. Rate -growth dynamics for heat energy in Saint-Petersburg since 2006 till 2011 in the case of central heating supplies.

\begin{tabular}{|c|c|l|}
\hline Year & $\begin{array}{c}\text { Rate value, Rub/Gcal } \\
\text { (incl. VAT) }\end{array}$ & \multicolumn{1}{c|}{ Grounds } \\
\hline 2006 & 500.40 & $\begin{array}{l}\text { Administrative order of the Regional energy commission issued by } \\
\text { the Saint-Petersburg Government dated 16 November 2005 N 100- } \\
\mathrm{p}\end{array}$ \\
\hline 2007 & 575.46 & $\begin{array}{l}\text { Administrative order on the tariffs issued by the Saint-Petersburg } \\
\text { Government dated 15 November 2006 N 123-p }\end{array}$ \\
\hline
\end{tabular}




\begin{tabular}{|c|c|l|}
\hline 2008 & 650.00 & $\begin{array}{l}\text { Administrative order on the tariffs issued by the Saint-Petersburg } \\
\text { Government dated 31 October 200. N 139-p }\end{array}$ \\
\hline 2009 & 795.73 & $\begin{array}{l}\text { Administrative order on the tariffs issued by the Saint-Petersburg } \\
\text { Government dated 19 November 2008 N 141-p }\end{array}$ \\
\hline 2010 & 931.00 & $\begin{array}{l}\text { Administrative order on the tariffs issued by the Saint-Petersburg } \\
\text { Government dated 14 December 2009 N 199-p }\end{array}$ \\
\hline 2011 & 1050.00 & $\begin{array}{l}\text { Administrative order on the tariffs issued by the Saint-Petersburg } \\
\text { Government dated 13 December 2010 N 334-p }\end{array}$ \\
\hline
\end{tabular}

From the data, shown in the Table 2, it follows that during the period under consideration (from 2006 to 2011) an average value of the relative tariff growth for heat energy per year $\Delta \mathrm{C}_{\mathrm{h}}$ accounted to $16 \%$. Thus let's take an average annual tariff growth for heating energy $\mathrm{r}$ equal to 0.16 .

Let's assume discounting of future cash flows (i) at the key interest rate CB RF (11\%), i.e. the parameter $i$ when calculating the payback period of investments will be 0.11 .

On the grounds of the data obtained let us calculate the payback period of investments into façade insulation in the existing building. And we will obtain:

$$
T=\frac{\ln \left[1+\frac{\Delta \tilde{K}}{\Delta \ni} \cdot \frac{(r-i)}{(1+i)}\right]}{\ln \left[\frac{1+r}{1+i}\right]}=\frac{\ln \left[1+\frac{2386.8}{94.1} \cdot \frac{(0.16-0.11)}{(1+0.11)}\right]}{\ln \left[\frac{1+0.16}{1+0.11}\right]}=17.3 \text { (years) }
$$

Provided a construction company uses own (non-borrowed) resources for façade renovation works with subsequent insulation, the payback period will be:

$$
T=\frac{\ln \left[1+\frac{\Delta K}{\Delta \ni} \cdot \frac{(r-i)}{(1+i)}\right]}{\ln \left[\frac{1+r}{1+i}\right]}=\frac{\ln \left[1+\frac{1950}{94,1} \cdot \frac{(0.16-0.11)}{(1+0.11)}\right]}{\ln \left[\frac{1+0.16}{1+0.11}\right]}=15.0(\text { years })
$$

\section{Conclusion}

Thus with the current economic situation and tariffs in Russia the payback period of investments into insulation of the facades in the existing building under Saint-Petersburg climatic conditions will account for less than 18 years. Notes. The calculations and conclusions given above are true provided there is renovation (insulation) of the facades and simultaneous setting up of AHSCU (automated heat supply control unit) upon putting the building in operation. Otherwise, insulation facades may result in increase of the inside air temperature in the buildings maintained and failure of the estimated rebound effect for energy efficiency (actual reduction of operational and maintenance costs $\Delta \ni$ may appear to be less than estimations).

The factors, which positively impact on the reduction of the payback period of the investments into renovation of the facades, are as follows:

- advance rate-growth of tariffs for heat energy (r);

- reduction of bank loan interest rates (pl);

- inflation and risks inflation (i);

- increase of the parameter $\Delta \ni$, which shows the difference between heat losses through $1 \mathrm{~m} 2$ of an exterior wall before and after insulation works of facades in the existing building (increase of $\Delta \ni$ may be achieved only due to magnifying the thickness of the insulation layer, and this will automatically lead to increase in capital $\operatorname{costs} \Delta \widetilde{K}$, and it is unknown which of these parameters will be increasing faster);

- reduction of the capital costs for heating $\Delta \widetilde{K}$ (though it may lead to impairing quality of 
construction and assembly works).

For this reason the actual objective factors, which contribute to reduction of the forecasted return on investments according to the formula (5), will be the difference (r-i) between annual relative rate growth and the coefficient, which shows discounting of future cash flows (inflation, risks, alternative investments and others), and reduction of bank loan interest rates (pl) provided the company uses the loan with the purpose to implement this energy-saving activity as well.

For this very reason a number of EU countries have grants aimed at reconstruction of buildings. In Germany, there is a state programmer «Energy reconstruction», according to which a set of reconstruction measures was approved, with the purpose to reach the level of energy saving such as Effizienzhaus 100 and Effizienzhaus 85 [20]. The group of German state banks KfW (Kreditanstalt für Wiederafbau) provide gainful loans and grants to implement energy-efficient reconstruction making it possible to reduce return on investment, as it follows from the analysis of the equation (5) and calculation example mentioned above.

\section{References}

1. N. Harmati, Z. Jakšić, N. Vatin, (2015) Procedia Engineering, 117 (1), $791-799$ (2015)

2. Y.A. Tabunschikov, M.M. Brodatch, ASHRAE Journal, 48 (11), 26-31 (2006)

3. Y. Tabunschikov, M. Brodatch, Supplement, 14 (SUPPL. 7), 168-174 (2004)

4. N. I. Vatin, D. V. Nemova, P. P. Rymkevich, A. S. Gorshkov, Inzhenerno-stroitel'nyj zhurnal, 34, 4-14 (2012)

5. V.V. Okrepilov, V.N. Krutikov, G.I. El'kin, Measurement Techniques, 57 (2),109-116 (2014)

6. V.V. Okrepilov, A.Yu. Smirnov, Measurement Techniques, 56 (1), 54-60 (2013)

7. V.V. Okrepilov, Studies on Russian Economic Development, 24(1), 35-42 (2013)

8. A. S. Gorshkov, Stroitel'nye materialy, 8, 12-17 (2009)

9. A. S. Gorshkov, D. Y. Popov., A. V. Glumov, Inzhenerno-stroitel'nyj zhurnal, 8, 5-8 (2010)

10. A. S. Gorshkov, M. V. Knat'ko, P. P. Rymkevich, Inzhenerno-stroitel'nyj zhurnal, 8, 20-26 (2010)

11. A. S. Gorshkov, P. P. Rymkevich, I. I. Pestrjakov, M. V. Knat'ko, Stroitel'nye materialy, 9, 49$53(2010)$

12. A. N. Dmitriev, Y. A. Tabunshhikov, I. N. Kovalev, N. Shilkin, AVOK-PRESS, 9, 8-13 (2005)

13. Y. A. Tabunshhikov, N. V. Shilkin, AVOK, 7, 10-21 (2005)

14. G. P. Vasil'ev, Energosberezhenie, 6, 14-23 (2011)

15. STO SPPP 4.5-2012 Raschetnyj metod ocenki jekonomicheskoj jeffektivnosti jenergosberegajushhih svetoprozrachnyh konstrukcij (SPbPU, St. Petersburg (2012)

16. A. S. Gorshkov, Energosberezhenie, 4, 12-19 (2014)

17. A. S. Gorshkov, P. P. Rymkevich, Stroitel'nye materialy, oborudovanie, tehnologii XXI veka, 188, 40-45 (2014)

18. A. S. Gorshkov. Inzhenernye sistemy. Rukovodstvo po proektirovaniju, stroitel'stvu $i$ rekonstrukcii zdanij s nizkim potrebleniem jenergii (SPbPU, St. Petersburg (2013)

19. A. S. Gorshkov, P. P. Rymkevich, D. V. Nemova, N. I. Vatin, Inzhenernye sistemy. AVOK Severo-Zapad, 3, 32-36 (2014)

20. Gabriyel, I., Ladener, Kh. Rekonstruktsiya zdaniy po standartam energoeffektivnogo doma (St. Peterburg: BKhV-Peterburg, 2011) 